(The 3rd ICBS-2013)

\title{
VEGETATION ANALYSIS IN PART OF CATCHMENT AREA INFLUENCING WATER QUALITY IN CIKAPUNDUNG UPSTREAM, SUNTENJAYA VILLAGE, WEST BANDUNG REGENCY
}

\author{
Retno Peni Sancayaningsih and Amarizni Mosyaftiani \\ Laboratory of Ecology and Conservation, Faculty of Biology, \\ Gadjah Mada University, Yogyakarta
}

\begin{abstract}
Plant coverage and land-use practices in catchment area influence water quality of the stream. Vegetation analysis in the catchment area of Cikapundung upstream was studied in three land-use areas: Production Forest (HP), Plantation (PK), and Settlement (PM) areas. The objective of this study was to analyze the vegetation as cover ground, and to relate between land uses and water quality of the Cikapundung stream. Research was conducted from February to April 2013. Equally random sampling method was conducted in three accessible land use areas with a total of 18 nested square plots $\left(20 \times 20 \mathrm{~m}^{2} ; 10 \times 10 \mathrm{~m}^{2}\right.$ and $\left.1 \times 1 \mathrm{~m}^{2}\right)$ of each growth forms.

There were 59 species found in the catchment area of Cikapundung upstream consisting of trees, saplings, seedlings, shrubs, herbaceous and grasses growth forms. Among two other land uses, PK had the highest (37) plant species, and HP had the highest diversity index (2,78). Similarity indices of total vegetation between HP-PK; PK-PM; and PM-HP were 12.3\%,4.8\%, and 10.1\%. The highest similarity indices performed in trees was between HP-PK of $75 \%$, while similarity indices both herbaceous plants and grasses were shown between PK-PM; and between PM-HP with the figures of $62 \%$, and $70 \%$ respectively. Overall, herbaceous and grasses coverage dominated the catchment area of PM, HP, and PK, with the figures of $63 \%, 46 \%$, and $43 \%$ respectively. Based on water quality standard, the best water quality was in HP. However, the streams in all stations have been polluted by coliform, due to bio-fertilizer applications.
\end{abstract}

Keywords: catchment area, Cikapundung upstream, land-use practices, water quality

\section{INTRODUCTION}

Suntenjaya village is located in Lembang sub-subdistrict, West Bandung subdistrict. This village has a4.556,56 $\mathrm{km}^{2}$ area, located in the water resources protection area of North Bandung (Kawasan Bandung Utara, KBU) with an elevation of $1200-1300$ above sea level (asl). There are 6 water springs emerging from this village as the water catchment area of the upstream of Cikapundung river. Based on the $1988 \mathrm{KBU}$ master planby the local government of North Bandung (RUTR KBU), $72.5 \%$ of the catchment area is designated as the protectionarea, and $17.6 \%$ as the culture area (Hernawan et al., 2010). As the catchment area, KBU supplies $60 \%$ of ground water as clean water resources for Bandung city. Within 10 years (1992 - 2002), some forest and rice fields decreased significantly, up to $68 \%$ forest converted into settlements and abandon lands. A catchment area should have aminimum $30 \%$ coverage of forest to absorb rainwater and reduce water runoff. In fact the forest area in the Cikapundung catchment area is very anxiety (Soenarto, 1995; Effendy, 1997; Darsiharjo, 2004). The massive changing forland function greatly affect the rate of uptake of water into the soil, local climate changing, and widespread critical land (Butler et al., 2005; Lestiana, 2004). 
According to watershed management data of Citarum, upstream Cikapundung watershed contains many land-uses, including: secondary forest and dry land, production forest, human settlements, rainfed agriculture and mix garden, irrigated rice fields, and open area with percentage of $12.8 \%, 0.13 \%, 46.0 \%, 35.8 \%, 4.7 \%$, and $0.5 \%$ respectively(BPDAS Citarum Ciliwung, 2006) with maximum average rainfall of $89 \mathrm{~mm}$ (USAID, 2007).

When land conversion on protected water catchment areas carry on, water discharge and water quality of upstream river decrease gradually (Ruswandi et al., 2007). Water quality and water discharge in the river ecosystem depend mostly on the environment, including condition of the water catchment area, rainfall, and landuse (Horne \& Goldman, 1994). Water resource as drinking water exploited from water reservoir should meet some criteria as follows: high dissolved oxygen (DO), low phosphate and nitrate contents, low suspended solid material and organic material, and high diversity of biotic organisms (Nolte and Loose, 2004). These conditions initiate this study that focus on the relation between different land uses (production forest, vegetable orchard, and human settlements) to water quality in the upstream Cikapundung river in Suntenjaya village, KBU.

\section{MATERIALS AND METHODS}

The study was carried out in a part of water catchment area at the upstream of Cikapundung river, Desa Suntenjaya village, Lembang subdistrict, West Bandung regency. A survey of the location was done in January 2013 , then the whole study was conducted from February to May 2013.

Three stations were selected based on land use data, these are: production forest (HP), orchard (PK), and human settlements (PM) (Figure 1 and 2.).

1. HP station is a part of water catchment area located at the slope of Bukit Tunggul hill, it is an upstream river order 2. Coordinate of the HP station is N107049' 45"; W6 $43^{\prime} 32^{\prime \prime}$ with site elevation of $1,445 \mathrm{~m}$ asl. (Figure 2a.)

2. PK station is a part of water catchment area close to a production forest that is used by people as a vegetable orchard. It is located at the upstream river order 1. Coordinate of

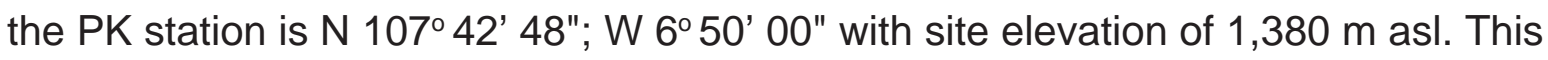
station is adjacent to settlements and poultry and dairy at the south boundary, and at the east boundary is adjacent to a production forest (Quinine and Cajuput). (Figure 2b.)

3. Human settlement station (PM) is located at the end of upstream sub-watershed Cikapundung river with order 4 where some housing already existed. Coordinate of the PK station is N 107 42' $33^{\prime \prime}$; W 6 $6^{\circ} 50^{\prime} 03^{\prime \prime}$ with site elevation of $1,335 \mathrm{~m}$ asl (Figure $2 \mathrm{c}$.) Study plotsfor vegetation analysis were taken using the Stratified Random Samplingmethod and vegetation distribution and abundance was carried out in 18 nested plots using square plots of $20 \times 20 \mathrm{~m}^{2}, 10 \times 10 \mathrm{~m}^{2}$, and $1 \times 1 \mathrm{~m}^{2}$ sizes for trees, saplings, and floor vegetation consecutively.

Water quality including physical, chemical, and biological parameters, and environmental factors surrounding Cikapundung river in each station were recorded. Vegetation parameters of each growth form and ecological indices in each study site as well as width coverage of growth forms were calculated. 


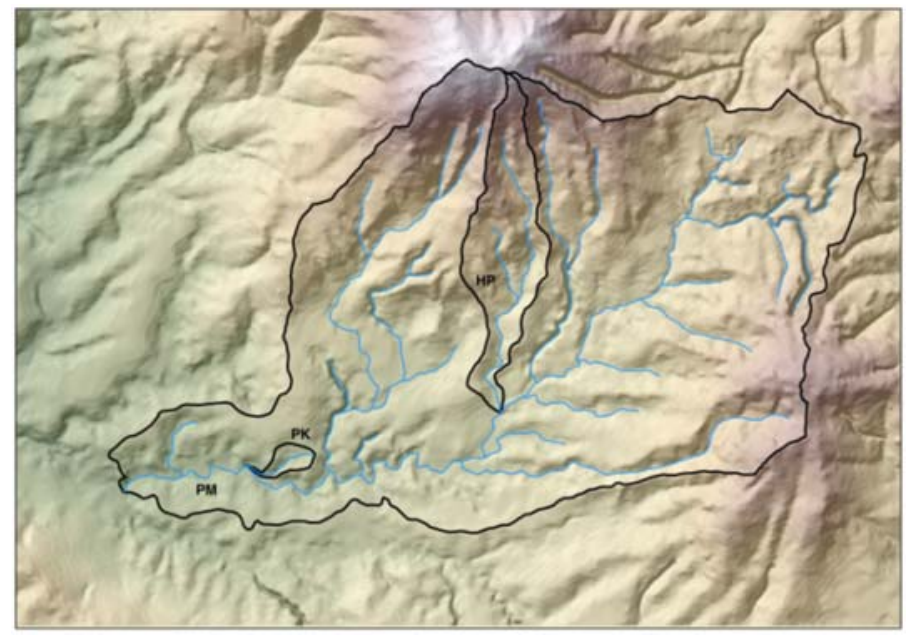

Figure 1. Catchment area of upstream Cikapundung river, Suntenjaya, West Bandung.

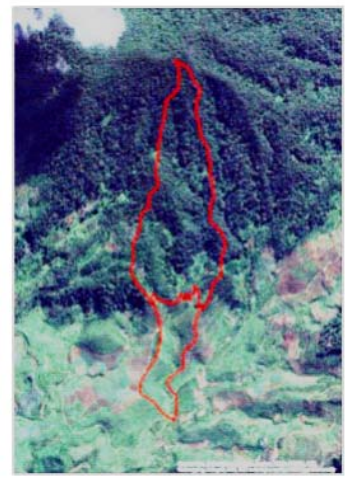

(a)

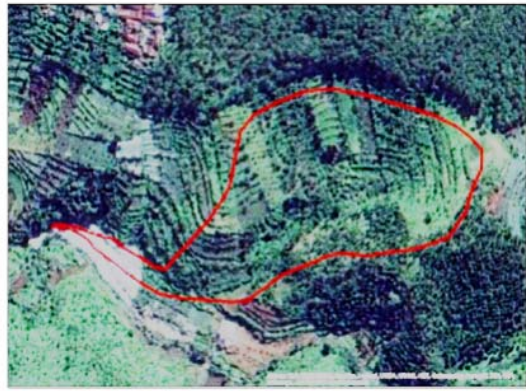

(b)

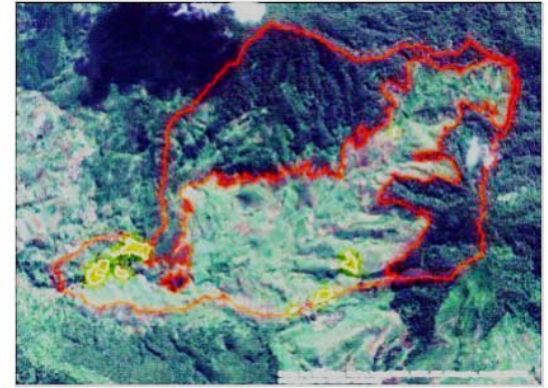

(c)

Figure 2. Study sites selected in water catchment area at upstream of Cikapundung river, Suntenjaya, West Bandung, including (a) production forest (HP); (b) vegetable orchards $(\mathrm{PK})$; and (c) human settlements (PM)

\section{RESULTS AND DISCUSSION}

Figure 1 showed the number of species composed in three different land-uses, HP, PK, and PM by growth-form group. The highest number of species was in PK station, with 37 species, followed by PM and HP with the number of species of 30 and 28 respectively. Herbaceous specieshad the highestcomposition species: 17 species (PK), 12 species (PM) and 11 species (HP).

Generally, importance value of grasses, and herbaceous were higher than trees, shrubs, and sapling groups (Figure 4.). In terms of vegetation density and frequency, again herbaceous and grasses played important roles in water conservation in the water CA at the upstream of Cikapundung river. Land covered with grasses may reduce water erosion up to 0.540 ton/ha/yr if the percentage of water rainfall is $1.5 \%$ (Triwanto, 2012). Both herbaceous and shrubs contributed $57.2 \%$ and grasses contributed $42.7 \%$ of land coverage.

Trees and sapling species found in 3 study sites were very diverse from one site to the other, except the only species of Eucalyptus alba found in all study sites. This distribution might be influenced by human settlements, since this grow in HP, PK, as well as PM (Table 


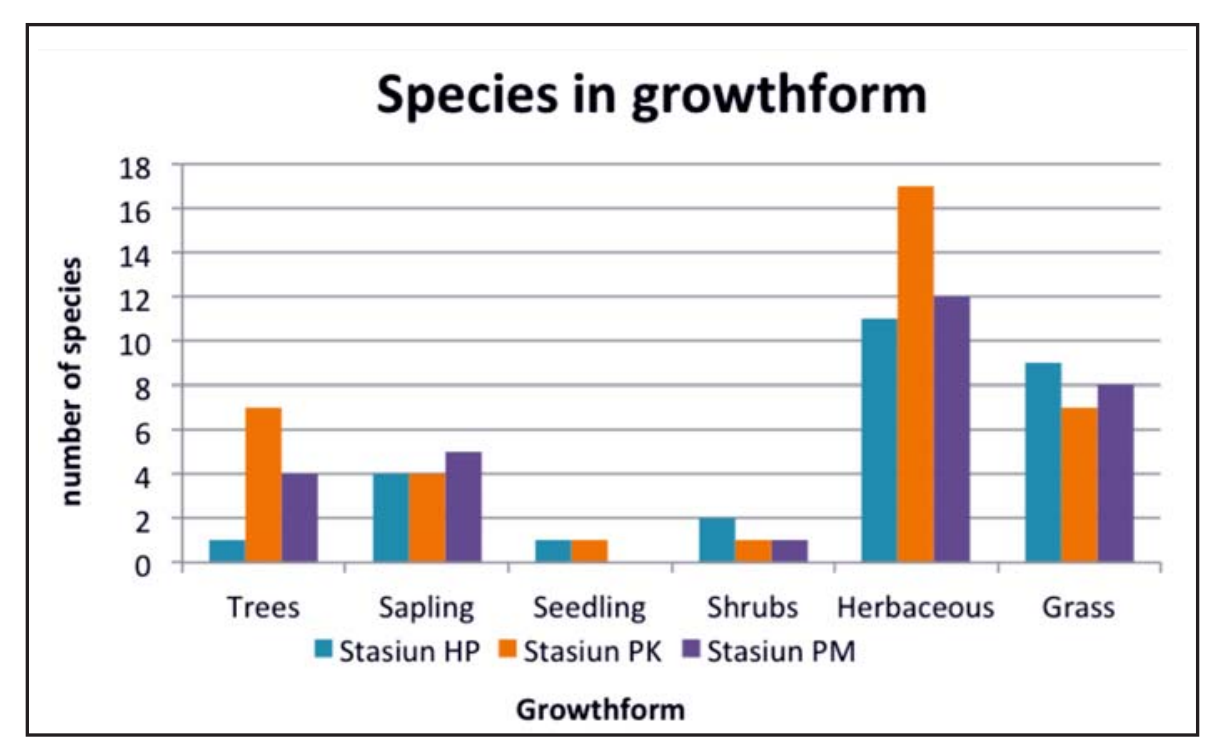

Figure 3. Species richness of vegetation in 3 different land-uses grouped by their growthforms

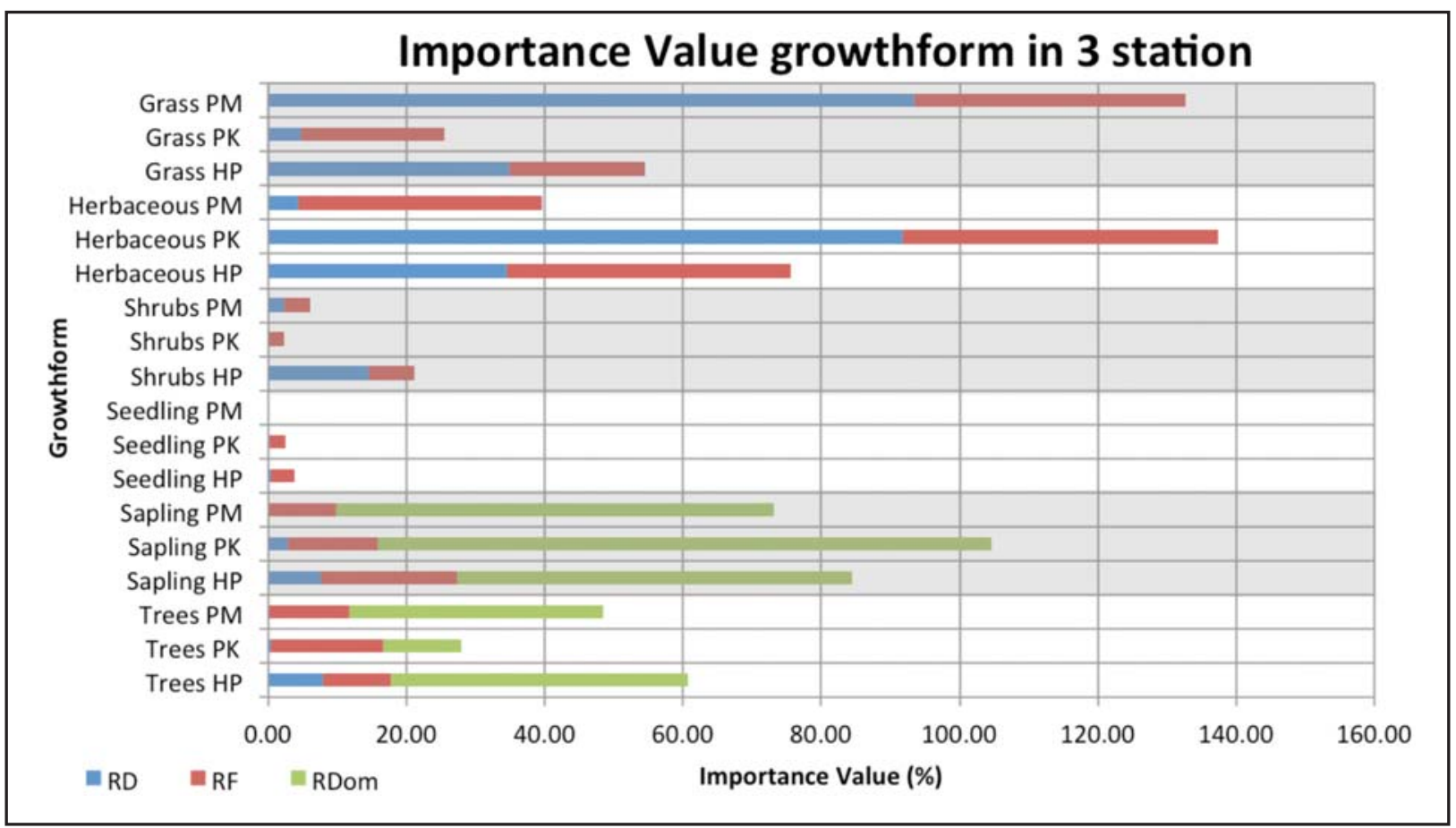

Figure 4. Importance value of vegetation based on growth-form in HP, PK, and PM stations

1.). This species are probably grown by societies due to economical consideration of the species.

In terms of species richness, trees and saplings species represented only $0.1 \%$ of the whole study sites (Table 5.). Twenty two species of trees and saplings were found in the catchment area, in HP, PK and PM stations each was composed of 5, 11, and 9 species respectively (Table 1.), with very low density (less than $0.1 \mathrm{~m}^{-2}$ ).

Unlike trees trend, there were 27 species of shrubs and herbalgrowth-forms with a very high variety of plant density, ranging from 0.17 to 375 individu $\mathrm{m}^{-2}$ (Table 2.). Each stations was composed of 13,17, and 12 species for HP, PK, and PM stations consecutively. Three dominant species for HP were Hedyotis capitellata, Drymaria hirsuta, andOxalis barrelieri, 
Table 1. Major tree and sapling density at 3 different stations:Production Forest (HP), Orchard (PK) and Settlements (PM) at the water catchment area in upstream Cikapundung river, Suntenjaya village, west Bandung.

\begin{tabular}{lccc}
\hline \multicolumn{1}{c}{ SPESIES } & $\mathrm{HP}\left(\mathrm{m}^{-2}\right)$ & $\mathrm{PK}\left(\mathrm{m}^{-2}\right)$ & $\mathrm{PM}\left(\mathrm{m}^{-2}\right)$ \\
& 5 & 11 & 9 \\
\hline Artocarpus heterophyllus & & 0.0008 & 0.0004 \\
Eucalyptus alba & 0.0342 & 0.0004 & 0.0021 \\
$\begin{array}{l}\text { Pinus merkusii } \\
\text { Toona sureni }\end{array}$ & & 0.0004 & 0.0004 \\
Kakia & & 0.0008 & 0.0004 \\
\hline SAPLINGS & & \\
\hline Anthocephalus cadamba & & 0.0583 & \\
Cinchona ledgerina & $\mathbf{0 . 0 8 3 3}$ & & 0.0133 \\
Cinchona succirubra & 0.0133 & & 0.0133 \\
Eucalyptus alba & 0.0333 & & 0.0050 \\
Manihot utilissima & & 0.0700 & \\
\hline
\end{tabular}

Table 2. Major shrub and herbaceous growth forms density at 3 different stations: Production Forest (HP), Orchard (PK) and Settlements (PM) at the water catchment area in upstream Cikapundung river, Suntenjaya village, west Bandung.

\begin{tabular}{lccc}
\hline \multicolumn{1}{c}{ SPESIES } & $\mathrm{HP}\left(\mathrm{m}^{-2}\right)$ & $\mathrm{PK}\left(\mathrm{m}^{-2}\right)$ & $\mathrm{PM}\left(\mathrm{m}^{-2}\right)$ \\
\hline Eupatorium riparium & 13 & 17 & 12 \\
Hedyotis capitellata & 24.83 & 0.33 & 17.17 \\
Ageratum conyzoides & 7.50 & 7.50 & 2.50 \\
Drymaria hirsuta & 12.67 & 375.00 & 6.83 \\
Euphorbia hirta & & 3.67 & \\
Sida rhombifolia & 1.83 & 1.17 & 4.33 \\
Centella asiatica & 5.83 & & 12.50 \\
Graminae & 4.17 & 3.00 & 3.50 \\
Oxalis barrelieri & 9.17 & & \\
Euphorbia & 8.50 & & \\
Polygonum nepalense & 8.00 & 15.33 & 0.17 \\
Acanthaceae & & 3.50 & \\
\hline
\end{tabular}

while for PK weredominated by Drymaria hirsuta, Polygonum nepalense, and Ageratum conyzoides; and PM station was dominated by Eupatorium riparium, Centella asiatica, and Drymaria hirsuta (Table 2.)

According to $\mathrm{Wu}$ (2011), Drymaria hirsutais an alien and invasive species from South America, and in HP station this was categorized as a weed. In another site, its high distribution may cover floor vegetation in the water catchment area, but as an invasive species it become outcompete toother species that grow in the same habitat (Hanna and Hotson 2004).

Three dominant grass species in three land-use areas shown that each land-use area has a specific habitat for certain grass species, among three stations, PK had the lowest grass species and densities. This might be because of farmer weeding practices regularly in PK. In the contrary, both HP and PM stations had high grass abundances. Major grass species dominated HP, were Kyllinga monocepala and Cynodon dactylon;PK was dominated by $C$. dactylon and Phalaris arundinaceae, and finally PM was dominated by $C$. dactylonand Pennisetum purpureum (Table 3.). This showed that $C$. dactylon was aggres- 
sive, pioneer species, and distributed easily in many different habitats.

Table 3. Major grasses density at 3 different stations: Production Forest (HP), Orchard (PK) and Settlements (PM) at the water catchment area in upstream Cikapundung river, Suntenjaya village, west Bandung.

\begin{tabular}{|c|c|c|c|}
\hline SPESIES & $\begin{array}{c}\mathrm{HP}\left(\mathrm{m}^{-2}\right) \\
9\end{array}$ & $\begin{array}{c}\mathrm{PK}\left(\mathrm{m}^{-2}\right) \\
7\end{array}$ & $\begin{array}{c}\mathrm{PM}\left(\mathrm{m}^{-2}\right) \\
8\end{array}$ \\
\hline $\begin{array}{l}\text { Commelina } \\
\text { benghalensis }\end{array}$ & & & 19.17 \\
\hline Cynodon dactylon & 13.50 & 4.83 & 623.33 \\
\hline Cyperus rotundus & & 4.67 & 4.67 \\
\hline Kyllinga monocepala & 28.50 & & 6.83 \\
\hline $\begin{array}{l}\text { Pennisetum } \\
\text { purpureum }\end{array}$ & & 0.17 & 63.67 \\
\hline Phalaris arundinaceae & & 4.83 & 10.33 \\
\hline Leersia hexandra & 5.83 & & \\
\hline Paspalum & 5.67 & & \\
\hline
\end{tabular}

Table 4. Ecological indices among three stations, HP, PK and PM at upstream water catchment area in Cikapundung river, Suntenjaya village, West Bandung Regency.

\begin{tabular}{lccc}
\hline & HP & PK & PM \\
\hline Diversity (Shannon-Wiener) & $\mathbf{2 . 7 8}$ & 0.99 & 0.97 \\
\hline Evenness & $\mathbf{0 . 8 3}$ & 0.27 & 0.29 \\
\hline Richness & 3.9 & $\mathbf{4 . 6}$ & 3.4 \\
\hline Similarity between HP (\%) & - & $\mathbf{1 2 . 3}$ & 10.1 \\
\hline Similarity between PK & - & - & 4.8 \\
\hline
\end{tabular}

Some ecological indices among three different stations showed that in terms of diversity, species richness, and evenness, production forest (HP) had the highest value (Table 4.). This means that the environmental condition, including vegetation coverage, adjacent to HP was still good to insure water quality of upstream Cikapundung river.Similarity index between HP and PK was the highest, even though still less than $50 \%$, this means that species diversity was varied among stations.

Vegetation coverage in CA greatly affects the quality of upstream water in the surrounding areas, as described by Triwanto (2012) and Trimble (1999). Table 5 showedtrees and sapling land coverage as well as herbs and grasses in broad CA at each station. Part of CA in PM station is covered only by a little amount of trees and saplings to width of CA. In PM station, coverage of treesand saplings had the least percentage, only $0.03 \%$. On the other hand, floor vegetation (herbs and grasses) had the greatest percentage, reaching63.08\%. (Table 5).

With this vegetation coverage, land use and excessive fertilization activity may lead to a potential decrease of water quality continuously.

The same thing happens also in PK station, with tree and sapling coverage justhave $1.03 \%$. In PK station, abundant of herbaceous plants dominated up to $43.29 \%$. This condition cannot accommodate rain water entering the ground because of the small plants morphology, so the sediment can be carried pretty much with the flow of water coming into the 
river. Presence of high turbidity in the river flow can be indicative of the sediment carried by the CA's pretty much go into the river.

Table 5. Vegetation coverage of each study sites (PH, PK and PM) based on growthform at the upstream water catchment area in Cikapundung river, Suntenjaya village, West Bandung Regency.

\begin{tabular}{|c|c|c|c|c|}
\hline Growth form coverage & HP & PK & PM & $\begin{array}{c}\text { percentage } \\
(\%)\end{array}$ \\
\hline Water catchment width $(\mathrm{m} 2)$ & $\begin{array}{r}522,710.1 \\
(9.9 \%)\end{array}$ & $\begin{array}{r}41,488.7 \\
(0.8 \%)\end{array}$ & $\begin{array}{r}4,735,887.1 \\
(89.4 \%)\end{array}$ & \\
\hline Trees density coverage & $17,859.3$ & 24.2 & $3,946.6$ & $0.03 \%$ \\
\hline $\begin{array}{l}\text { Sapling and seedling density } \\
\text { coverage }\end{array}$ & $17,205.9$ & $1,365.7$ & $41,439.01$ & $0.07 \%$ \\
\hline $\begin{array}{l}\text { Shrubs and herbaceous } \\
\text { density coverage }\end{array}$ & $4,791,508.8$ & $15,869,412.6$ & $28,099,596.7$ & $57.2 \%$ \\
\hline Grasses density coverage & $5,836,580.4$ & $175,580.1$ & $30,361,582.5$ & $42.7 \%$ \\
\hline Total growth form coverage & $10,663,154.4$ & $16,046,382.6$ & $58,506,564.8$ & \\
\hline Percentage & $12.5 \%$ & $18.8 \%$ & $68.7 \%$ & \\
\hline
\end{tabular}

Based on the Indonesian Ministry of Health Statement in 2002, a water resource should meet thedrinking water standard if it is used for a water supply. Physicochemical and biological conditions of the water quality in threeland-use areas at Cikapundung upstream are still below the threshold. However, the turbidity exceeds 5 NTU, in the upstream CA in PK and PM, coliform bacteria content (at all stations) does not meet water quality standards. Therefore, water resource need to be processed by PDAM (drinking water management) of Bandung City (Table 6).

Table 6. Water quality at three study sites (PH, $\mathrm{PK}$, and $\mathrm{PM})$ at upstream water catchment area in Cikapundung river, Suntenjaya village, West Bandung Regency.

\begin{tabular}{rlcccccc}
\hline \multirow{2}{*}{ No } & \multirow{2}{*}{ Water quality parameter } & \multicolumn{2}{c}{ HP station } & \multicolumn{2}{c}{ PK station } & \multicolumn{2}{c}{ PM station } \\
\cline { 2 - 7 } & & Average & SD & Average & SD & Average & SD \\
\hline 1 & Water pH & 6.84 & 0.47 & 6.42 & 0.24 & $\mathbf{6 . 7 8}$ & 0.39 \\
2 & DO (ppm) & $\mathbf{6 . 4 8}$ & 0.16 & 6.27 & 0.17 & 6.47 & 0.15 \\
3 & Turbidity (NTU) & 4.56 & 2.70 & $\mathbf{4 6 . 0 6}$ & 8.13 & 15.32 & 8.56 \\
4 & CO $_{2}(\mathrm{ppm})$ & 6.00 & 0.50 & $\mathbf{9 . 8 0}$ & 1.52 & 7.70 & 0.27 \\
5 & Flow rate (m/s2) & 0.86 & 0.29 & 0.53 & 0.12 & $\mathbf{1 . 4 9}$ & 0.94 \\
6 & Alkalinity (ppm) & 17.20 & 1.78 & $\mathbf{2 2 . 8 0}$ & 3.03 & 19.20 & 0.89 \\
7 & Water temperature $\left({ }^{\circ} \mathrm{C}\right)$ & 17.70 & 0.45 & $\mathbf{1 9 . 2 0}$ & 0.45 & 18.80 & 0.57 \\
8 & Light intensity (lux) & 624.00 & 151.3 & $\mathbf{6 0 6 . 0 0}$ & 109.22 & 564.00 & 120.33 \\
9 & Discharge (m3/s) & $4,793.5$ & 1169.2 & 669.9 & 101.2 & $\mathbf{1 0 , 0 1 3 . 2}$ & 5926.9 \\
10 & Nitrate (mg/L) & 3.78 & 0.34 & $\mathbf{8 . 4 4}$ & 5.13 & 6.74 & 3.48 \\
11 & Phosphate (mg/L) & 0.02 & 0.01 & $\mathbf{0 . 1 2}$ & 0.14 & 0.08 & 0.06 \\
& Fecal Coliform & & & & & & \\
12 & (number/100ml) & 55.0 & 77.8 & 396.5 & 499.9 & $\mathbf{8 , 0 5 0 . 0}$ & 9828.8 \\
& Total Coliform & & & & & & \\
13 & (number/100ml) & 55.0 & 77.8 & $3,150.0$ & 1626.4 & $\mathbf{8 , 0 5 0 . 0}$ & 9828.8 \\
\hline
\end{tabular}

Note: $S D=$ standard deviation, bold figures are the highest scores

There were 59 species found in the catchment area of Cikapundung upstream consisting of trees, saplings, seedlings, shrubs, herbaceous and grass growth forms. Among two other land uses, PK had the highest (37) plant species, and HP had the highest diversity index $(2,78)$.Similarity indices of total vegetation between HP-PK; PK-PM; and PM-HP were 
$12.3 \%, 4.8 \%$, and $10.1 \%$. The highest similarity indices performed in trees was between HPPK of $75 \%$, while similarity indices both herbaceous plants and grasses were shown between PK-PM; and between PM-HP with the figures of $62 \%$, and $70 \%$ respectively. Overall, herbaceous and grasses coverage dominated the catchment area of PM, HP, and PK, with the figures of $63 \%, 46 \%$, and $43 \%$ respectively. Based on water quality standard, the best water quality was in HP. However, the streams in all stations have been polluted by coliform due to bio-fertilizer applications and discharge from dairy and poultry wastes.

\section{REFERENCES}

Allan, J.D., and M.M. Castillo. 2007. Stream Ecology. Netherland: Springer.

Allen, J.C. 1985. Soil response to forest clearing in the United States and the tropics: geological and biological factors. Biotropica Vol 17(1); 15-27.

Barbour, M.G., J.H. Burk, W.D. Pitts, F.S. Gilliam, and M.W. Shwartz. 1999. Terresterial Plant Ecology. 3rd-ed. Menlo Park:The Benjamin/Cummings.

Bosch, J.M., and J.D. Hewlett.1982. A review of catchment experiments to determine the effect of vegetation changes on water yield and evapotranspiration. Journal of Hydrology 55:3-23.

BPDAS Citarum Ciliwung, Balai Pengelolaan Daerah Aliran Sungai Citarum Ciliwung. 2006. Buku 1 (Naskah) Laporan Karakteristik DAS Citarum. Bogor: BPDAS Citarum Ciliwung.

Darsiharjo. 2004. Model Pemanfaatan Lahan Berkelanjutan Di Daerah Hulu Sungai (Studi Kasus Daerah Hulu Sungai Cikapundung, Bandung Utara). [Disertasi]. Bogor: Sekolah Pascasarjana Institut Pertanian Bogor.

dePadua, L.S., N. Bunyapraphatsara, and R.H.M.J. Lemmens. 2003. Plant resources of South-East Asia No.12(1). Medicinal and poisonous plants 3. Netherland: Backhuys Publisher.

Effendy, R. 1997. Efek perubahan lingkungan Bandung terhadap proses resapan air tanah. Buletin Pusair Media Informasi Kegiatan Penelitian Keairan. 26:38-54.

Hanna, S., and A. Hotson. 2004. Report on Vegetation and Land Management In the Maguires Creek Catchment. Lismore: Training \&Employment INC.

Krebs, C.J. 1972. Ecology: The Experimental Analysis of Distribution and Abundance. New York: Harper and Row.

Nolte, U., and P. Loose. 2004. The stream health manual: the vision, the strategy, performance indicators, stream health classes. ISBN 09577523 EP. 1971. Fundamentals of Ecology. 3rd Ed. WB Saunders Co. Philadelphia.

Prawira, A.Y., K. Wikantika, and F. Hadi. 2005. Analisis spasial lahan kritis di kota bandung utara menggunakan open source grass. Pertemuan IImiah Tahunan MAPIN XIV p.100108.

Soenarto, B. 1995. Rekayasa peresapan buatan untuk mengatasi susutnya peresapan air alami akibat konservasi lahan alami menjadi lahan permukiman. Prosiding Seminar Sehati "Air tanah Cekungan Bandung". Satgas Penelitian Sumberdaya Air ITB Bandung, 12 Juli 1995. hlm 11411-58.

Triwanto, J. 2012. Konservasi Lahan Hutan Dan Pengelolaan Daerah Aliran Sungai. Universitas Muhammadiyah Malang Press. Malang. 
USAID. United States Agency for American People. 2007. Laporan Studi PES untuk Mengembangkan Skema PES di DAS Deli, Sumatra Utara dan DAS Progo, Jawa Tengah. Jakarta: ESP-USAID.

Wu, C.Y, P.H. Raven, and D.Y. Hong. 2011. Flora of China vol 19 Cucurbitaceae through Valerianaceae. Beijing \& St. Louis: Science Press \& Missouri Botanical Garden Press, pp.156-157. 